\title{
RADIONUCLIDES AS TRACERS OF COASTAL PROCESSES IN BRAZIL: REVIEW, SYNTHESIS, AND PERSPECTIVES
}

\author{
Isaac R. Santos ${ }^{\prime}$; William C. Burnett ${ }^{1}$ and José M. Godoy ${ }^{2}$ \\ ${ }^{1}$ Environmental Radioactivity Measurement Facility \\ Department of Oceanography, Florida State University \\ (Tallahassee, FL, 32306, USA) \\ *santos@ocean.fsu.edu \\ ${ }^{2}$ Instituto de Radioproteção e Dosimetria, Comissão Nacional de Energia Nuclear \\ (Av. Salvador Allende s/n, 22780-160 Rio de Janeiro, RJ, Brasil)
}

\begin{abstract}
We review the usefulness, limitations, significance, and coastal management implications of radionuclide measurements in Brazilian coastal environments. We focus on the use of radionuclides as tracers of sedimentary processes and submarine groundwater discharge (SGD). We also discuss artificial radionuclide contamination and high natural radioactivity areas. The interpretation of ${ }^{14} \mathrm{C}-,{ }^{137} \mathrm{Cs}-$, and ${ }^{210} \mathrm{~Pb}$-derived sedimentation rates has provided evidence that inappropriate soil use by urban and agricultural activities has intensified erosion processes on land, which is reflected in depositional environments, such as coastal lagoons, estuaries and mangroves. Of the processes discussed in this paper, SGD is the one that requires the most scientific effort in the short-term. There have been only two case studies using ${ }^{222} \mathrm{Rn}$ and radium isotopes as groundwater tracers in Brazil. These investigations showed that SGD can be a major source of nutrients and other dissolved species to the coastal ocean. Baseline ${ }^{137} \mathrm{Cs},{ }^{90} \mathrm{Sr},{ }^{239+240} \mathrm{Pu}$, and ${ }^{238} \mathrm{Pu}$ concentrations in seawater from the whole Brazilian coastal zone are very low. Therefore, in spite of contamination problems in many ecosystems in the northern hemisphere, artificial radionuclide pollution appears to be negligible along the Brazilian coast. Phosphate fertilizer industries and petroleum processing facilities are the main economic activities producing Technologically Enhanced Naturally Occurring Radioactive Materials (TENORM). Even though a few attempts have been made to assess the radiological effects of these activities, their potential threats indicate a need for the radiological control of their wastes. This review showed that the number of studies within the field of environmental radioactivity is still small in Brazil and much more research is needed to understand processes of high interest for environmental managers. In the near future, it is likely that such studies in Brazil will move from descriptive, environmental quality-based assessments to approaches that attempt to quantify chemical, physical, and biological processes in the environment.
\end{abstract}

\section{RESUMO}

Este artigo revisa a utilidade, limitações, importância e implicações para o gerenciamento costeiro das medições de radionuclídeos em ambientes costeiros do Brasil. O artigo enfoca o uso de radioisótopos como traçadores de processos sedimentares e descarga de água subterrânea na zona costeira. Também, é apresentada uma discussão sobre contaminação por radionuclídeos e áreas de alta radioatividade natural. A interpretação de taxas de sedimentação baseadas em ${ }^{14} \mathrm{C},{ }^{137} \mathrm{Cs}$ e ${ }^{210} \mathrm{~Pb}$ demonstra que o uso inadequado do solo por atividades agrícolas e urbanas intensificou os processos de erosão no continente, o que é refletido em ambientes deposicionais, como lagoas costeiras, estuários e manguezais. Existem apenas dois estudos de caso sobre o uso de isótopos como traçadores de água subterrânea no Brasil demonstrando que águas subterrâneas podem ser uma importante fonte de nutrientes e outras substâncias dissolvidas para o oceano. Uma melhor avaliação dos fluxos de água subterrânea para o mar parece ser uma das maiores prioridades científicas atuais na área de radioatividade ambiental. Os níveis de base de ${ }^{137} \mathrm{Cs},{ }^{90} \mathrm{Sr},{ }^{239+240} \mathrm{Pu}, \mathrm{e}{ }^{238} \mathrm{Pu}$ na água do mar, peixes, e sedimentos brasileiros são, em geral, bastante baixos. Portanto, apesar dos problemas de contaminação no hemisfério norte, a poluição por radionuclídeos artificiais ainda é desprezível no Brasil. Indústrias de fertilizantes fosfatados e refinarias de petróleo parecem ser as principais atividades econômicas produzindo rejeitos contendo materiais radioativos. Embora algumas investigações tenham determinado o efeito radiológico dessas atividades, suas ameaças potenciais demonstram a necessidade do controle de emissões. Este artigo demonstra que o número de investigações na área de radioatividade ambiental ainda é muito reduzido no Brasil e que pesquisas adicionais são necessárias para um melhor entendimento de processos de alto interesse para o gerenciamento ambiental. Nos próximos anos, é provável que os estudos sobre radioatividade ambiental no Brasil sejam focados em processos ambientais, em detrimento à abordagens descritivas de qualidade ambiental.

Descriptors: Environmental radioactivity, Coastal zone, Radioisotopes, Geochemical tracers.

Descritores: Radioatividade ambiental, Zona costeira, Radioisótopos, Traçadores geoquímicos. 


\section{INTRODUCTION}

Nowadays, nearly $37 \%$ of the world population lives within $100 \mathrm{~km}$ from the coast and population in coastal areas are growing much faster than in non-coastal areas (COHEN et al., 1997). This has changed ecosystem functioning and created conflicts between different human activities, such as fishing, tourism, transport, and agriculture. Brazil has one of the largest coastal regions ( $7500 \mathrm{~km}$ long) of the world ranging from an equatorial to a temperate climate (Fig. 1), with a great diversity of ecosystems, such as mangroves, coral reefs, cliffs, coastal lagoons, salt marshes, and dunes (DIEGUES, 1999; EKAU; KNOPPERS, 2003). Although coastal zone degradation may be detected almost everywhere, a large portion of the Brazilian coast is still relatively pristine, which may change due to increasing population densities.

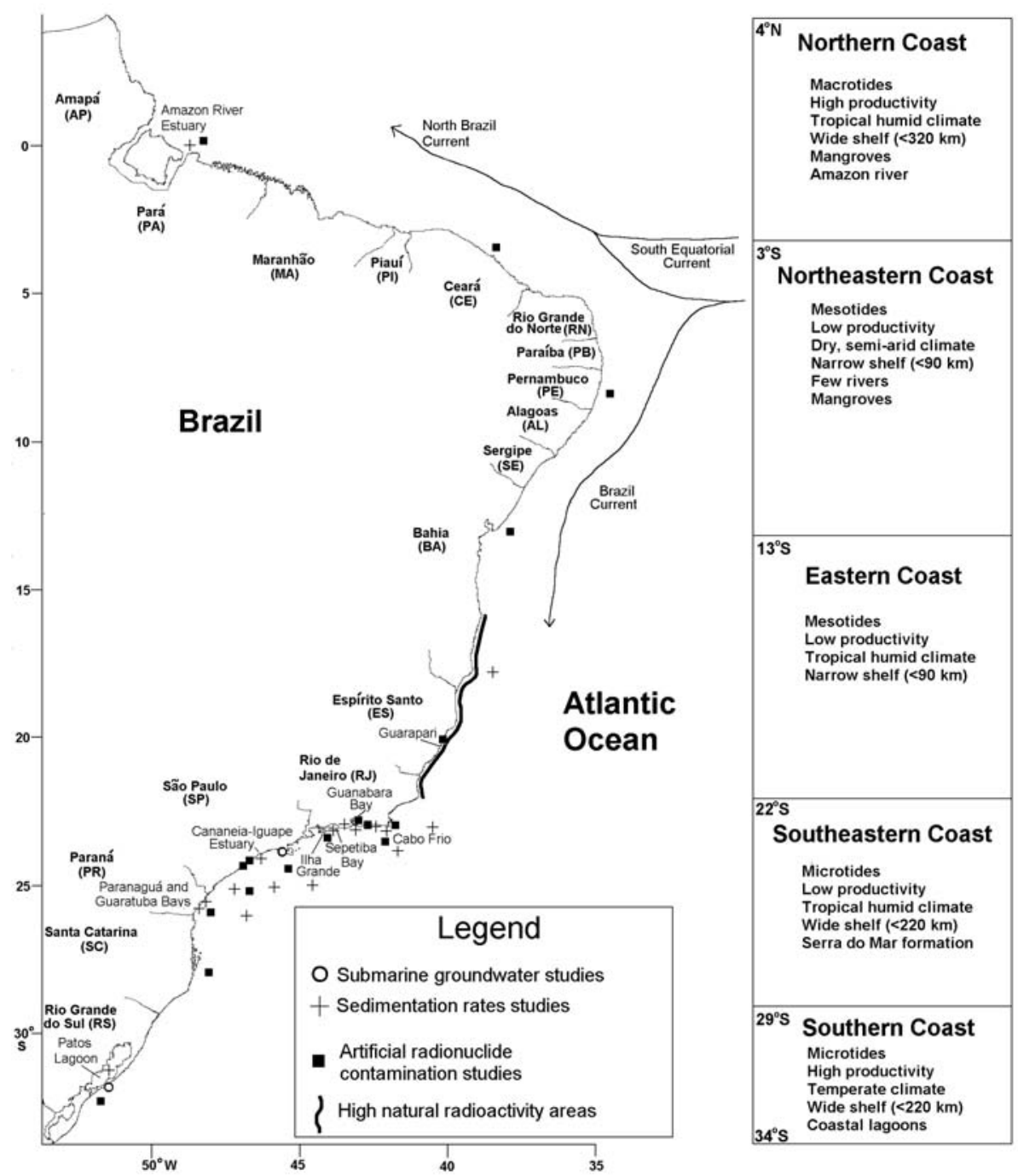

Fig. 1. Main features of the Brazilian coast (after EKAU; KNOPPERS, 2003) and the location of environmental radioactivity studies referenced herein. 
Both the development and conservation of Brazilian coastal environments are expected to be strongly related to the level of understanding of their functioning. The use of radionuclides for studying these environments can answer important scientific questions, which may be useful for coastal management and elaboration of conservation strategies. In recent years, radionuclides have been applied in environmental studies not only for radiological protection purposes, but also as tracers of complex processes. The diverse geochemical behavior and the wide-range of half-lives of different nuclides (Table 1) allow the investigation of processes taking place on the scales of most coastal processes (BOURDON et al., 2003; COCHRAN; MASQUE, 2004; COCHRAN et al., 2006). Sediment accumulation rates, transport of elements to the oceans, gas exchange, and water masses circulation are examples of processes that may be better understood via application of radionuclides.

Radionuclides are classified into four groups according to their origins: (1) cosmic-ray produced nuclides (such as ${ }^{7} \mathrm{Be}$ and ${ }^{14} \mathrm{C}$ ); (2) artificiallyproduced nuclides (such as ${ }^{137} \mathrm{Cs}$ and ${ }^{90} \mathrm{Sr}$ ); (3) primordial isotopes (such as ${ }^{238} \mathrm{U}$ and ${ }^{40} \mathrm{~K}$ ); and, (4) natural decay products (such as ${ }^{226} \mathrm{Ra}$ and ${ }^{222} \mathrm{Rn}$ ). The three naturally occurring radioactive decay chains include the ${ }^{238} \mathrm{U},{ }^{235} \mathrm{U}$, and ${ }^{232} \mathrm{Th}$, which decay through a series of radioactive elements up to stable $\mathrm{Pb}$ isotopes. Taking into account their different geochemical behaviors (Table 1), a number of natural processes (such as dissolution, adsorption, complexation, and oxidation/reduction) can cause disequilibria among these elements. Uranium, for instance, can be mobilized from sediments in oxic conditions as soluble $\mathrm{U}(\mathrm{VI})$, whereas reducing environments favor the precipitation of the insoluble $\mathrm{U}(\mathrm{IV})$. On the other hand, the $\mathrm{U}$ radioactivity daughter, Th, is insoluble, so disequilibrium between Th and U is commonplace (BOURDON et al., 2003).

In this paper, we review the environmental radioactivity studies carried out along the Brazilian coastal zone. We define the coastal zone as the transition area where land and ocean strongly interact with each other. It is very difficult to determine the exact extension of this area, but we define an area between the landward limit of brackish waters and the offshore edge of the continental shelf. We will not discuss the analytical methodologies for nuclide determination, but rather the usefulness, limitations, significance, and coastal management implications of their measurements in different environments.

Table 1. Summary of the behavior and applications of main radionuclides used for investigating coastal zone processes (after Bourdon et al., 2003 and Cochran et al., 2006).

\begin{tabular}{|c|c|c|}
\hline Radionuclide (half-life) & Geochemical behavior & Main applications \\
\hline${ }^{210} \mathrm{~Pb}(22.3 \mathrm{y})$ & Insoluble; scavenged onto particles & Mixing and sedimentation rates $(\sim 120$ years $)$ \\
\hline${ }^{137} \mathrm{Cs}(30 \mathrm{y})$ & $\begin{array}{l}\text { Insoluble; may dissolve when dissolved } \\
\text { cations are available in reducing conditions }\end{array}$ & Checking ${ }^{210} \mathrm{~Pb}$-derived sedimentation rates \\
\hline${ }^{7} \mathrm{Be}(53 \mathrm{~d})$ & $\begin{array}{l}\text { Produced in atmosphere, deposited in } \\
\text { Earth's surface, scavenged onto particles }\end{array}$ & $\begin{array}{l}\text { Sediment mixing and short-term }(\sim 1 \text { year }) \\
\text { sedimentation rates }\end{array}$ \\
\hline${ }^{234} \mathrm{Th}(24 \mathrm{~d})$ & $\begin{array}{l}\text { Highly insoluble, rapidly scavenged onto } \\
\text { particles }\end{array}$ & $\begin{array}{l}\text { Sediment reworking and short-term } \\
(\sim 5 \text { months }) \text { sedimentation rates }\end{array}$ \\
\hline${ }^{14} \mathrm{C}(5730 \mathrm{y})$ & $\begin{array}{l}\text { Produced in atmosphere and incorporated } \\
\text { by living organisms }\end{array}$ & $\begin{array}{l}\text { Geochronology ( } \sim 40000 \text { years) and air-water } \\
\text { gas exchange }\end{array}$ \\
\hline $\begin{array}{l}{ }^{226} \operatorname{Ra}(1600 \mathrm{y}) \\
{ }^{228} \mathrm{Ra}(5.7 \mathrm{y})\end{array}$ & $\begin{array}{l}\text { Conservative and soluble; released from } \\
\text { sediment to brackish and saline waters }\end{array}$ & $\begin{array}{l}\text { Submarine groundwater discharge rates, } \\
\text { water masses ages and mixing process }\end{array}$ \\
\hline${ }^{223} \operatorname{Ra}(11.4 \mathrm{~d})$ & & \\
\hline${ }^{222} \mathrm{Rn}(3.83 \mathrm{~d})$ & Volatile, conservative and soluble & $\begin{array}{l}\text { Groundwater discharge rates, diffusion in the } \\
\text { sediment-water interface and air-sea gas } \\
\text { exchange }\end{array}$ \\
\hline
\end{tabular}




\section{Sedimentation Rates}

Sediments provide a temporally integrated indication of the aquatic biogeochemical environment and act as a major reservoir for reactive elements in the coastal zone. They also preserve the environmental history of a drainage basin, and can be useful for making predictions about how future changes may alter a certain environment. Alterations in sediment loading can result from anthropogenic disturbances such as urban development, road construction, agriculture, and hydrologic changes (SMOAK; SWARZENSKI, 2004). A decrease in sedimentation rates may increase erosion in coastal zones. On the other hand, increasing sedimentation rates may silt up protected coastal sites such as estuaries, seagrass beds and mangroves (MOLISANI et al., 2004).

The input of anthropogenically-mobilized sediments has been considered one of the most important pollution problems in the coastal ocean because it may change the cycling of elements and interfere with economical activities. The lack of scientific information about the interrelationship between sources, transport, fate and effects of anthropogenically-mobilized sediments prevents the development of management strategies (WINDOM, 1992). Furthermore, a comprehensive understanding of regional sedimentation rates is useful for determining carbon fluxes and contamination histories. The alterations in sediment loading may be quantified and understood through the interpretation of radioactive nuclides in sediment cores. For example, ${ }^{210} \mathrm{~Pb}$ and ${ }^{14} \mathrm{C}$ have been extensively used and their application to understanding sedimentation processes is discussed below.

\section{Use of ${ }^{210} \mathrm{~Pb}$ and ${ }^{14} \mathrm{C}$ to Derive Sedimentation Rates}

${ }^{210} \mathrm{~Pb}$ is a product of the ${ }^{238} \mathrm{U}$ natural series decay chain and has two components within sediments. One is derived from in situ decay of ${ }^{226} \mathrm{Ra}$ (supported ${ }^{210} \mathrm{~Pb}$ ) and the other (unsupported or excess ${ }^{210} \mathrm{~Pb}$ ) is scavenged from the water column by sinking particles. In lakes and coastal sediments, unsupported ${ }^{210} \mathrm{~Pb}$ can originate from at least two sources: mobilization of sediments from the watershed and atmospheric deposition (from ${ }^{222} \mathrm{Rn}$ decay). Lead atoms in the atmosphere are readily attached onto airborne particulate material and removed by washout and dry deposition. In marine systems, unsupported ${ }^{210} \mathrm{~Pb}$ is basically supplied by radioactive decay of dissolved ${ }^{226} \mathrm{Ra}$ and subsequent scavenging to sediments (IVANOVICH; HARMON, 1992; CARROLL et al., 1999).

$\mathrm{Pb}-210$ is a suitable tracer for examining sedimentation processes taking place over timescales of about 100 years. There are many models to calculate sedimentation rates based on ${ }^{210} \mathrm{~Pb}$ profiles. If the ${ }^{210} \mathrm{~Pb}$ activity profile follows an exponential decrease with depth, it is possible to obtain sedimentation rates by dividing its decay constant $\left(\lambda=0.0311 \mathrm{y}^{-1}\right)$ by the slope of the log-linear plot of unsupported ${ }^{210} \mathrm{~Pb}$ versus depth. This model assumes a constant ${ }^{210} \mathrm{~Pb}$ flux and a constant sedimentation rate over time. By assuming that the activity of ${ }^{210} \mathrm{~Pb}$ at $\mathrm{t}$ equal to zero is the one observed at the surface of a particular core, it is possible to derive sedimentation rates through the Constant Initial Concentration model (CIC). This model also assumes that mixing has not taken place via physical or biological disturbances. Given these parameters, the CIC model may be applied to the unsupported ${ }^{210} \mathrm{~Pb}$ according to the following equation:

$t=(1 / \lambda) \ln \left(\mathrm{C}_{\mathrm{o}} / \mathrm{C}_{\mathrm{i}}\right)$

where $t$ is the age of the sediment at the ith horizon, $\mathrm{C}_{\mathrm{i}}$ is the excess ${ }^{210} \mathrm{~Pb}$ activity at the ith horizon, $\mathrm{C}_{\mathrm{o}}$ is the extrapolated activity at the surface and $\lambda$ is the decay constant of ${ }^{210} \mathrm{~Pb}$. By dividing the thickness of the sediment horizons by the difference in age, one can obtain the sedimentation rates assuming no compactation has occurred.

Another model that has been extensively used is the CRS (Constant Rate of Supply) (APPLEBY; OLDFIELD, 1983; ABRIL， 2003; SMOAK; SWARZENSKI, 2004). The basic assumptions of this model are that excess ${ }^{210} \mathrm{~Pb}$ was supplied to the sediments at a constant rate and that no post-depositional mixing has taken place. The great advantage of the CRS model is that the sedimentation rate can be variable, (e.g., the specific ${ }^{210} \mathrm{~Pb}$ activity decreases when the sedimentation rate increases), which allows one to make inferences about the historical variability of process within a particular hydrographic basin. The CRS model uses the total ${ }^{210} \mathrm{~Pb}$ inventory at the site and the inventory below the interval being dated to calculate an age according to the following equation:

$t=(1 / \lambda) \ln \left(\mathrm{A}_{0-\infty} / \mathrm{A}_{\mathrm{x}-\infty}\right)$

where $t$ is the age of the sediment at the ith horizon, $\mathrm{A}_{0-\infty}$ is the total inventory of the unsupported ${ }^{210} \mathrm{~Pb}$, and $A_{x-\infty}$ is the cumulative inventory of the unsupported ${ }^{210} \mathrm{~Pb}$ beneath the ith horizon.

${ }^{210} \mathrm{~Pb}$ chronologies should be validated using at least one independent tracer which separately provides an unambiguous time-stratigraphic horizon because many processes may invalidate some of the basic assumptions of dating models (SMITH, 2001). For this purpose, artificial fallout nuclides such as ${ }^{137} \mathrm{Cs},{ }^{241} \mathrm{Am}$, and $/$ or ${ }^{239} \mathrm{Pu}$ represent a useful tool. 
These bomb-produced radionuclides first appeared in measurable quantities in the environment in 1954 and reached a peak in 1963, when many atmospheric nuclear tests were performed. After that, atmospheric fallout of these radionuclides decreased and their deposition has been considered approximately constant. Thus, a peak of a fallout nuclide in a sediment profile is assumed to represent the year of 1963 , which may be used to calculate sedimentation rates and check the accuracy of ${ }^{210} \mathrm{~Pb}$ chronologies. Because ${ }^{210} \mathrm{~Pb}$ dating is often applied to sites with a known industrialization history, non radioactive tracers, as heavy metals and organic compounds, can also be applied as an independent check (SONKE et al., 2003; MARQUES JR. et al., 2006).

Radiocarbon $\left({ }^{14} \mathrm{C}\right)$ measurements in sediment cores and application of age models have also played an important role in coastal studies, being useful for dating sediments as old as $\sim 50,000$ years. This radionuclide is produced naturally at the top of the atmosphere by cosmic ray bombardment of ${ }^{14} \mathrm{~N}$ nucleus. When the ${ }^{14} \mathrm{~N}$ atom absorbs the neutron, a proton is expelled from the nucleus and $a{ }^{14} \mathrm{C}$ atom is formed. Once formed, the ${ }^{14} \mathrm{C}$ enters into the carbon cycle and is incorporated into organisms, including carbonate shells that make up a large proportion of sediments in many tropical environments. Basically, in order to calculate ${ }^{14} \mathrm{C}$-derived sedimentation rates one should use the simplest form of the law of radioactivity (equation 1). This seems simple at a first glance, but actually there are many complications involved in the process of converting ${ }^{14} \mathrm{C}$ activities into ${ }^{14} \mathrm{C}$ ages (STUIVER; POLACH, 1977).

The main problem is determining the initial activities of ${ }^{14} \mathrm{C}$. This might be solved by assuming that the production rate of ${ }^{14} \mathrm{C}$ is constant and uniform in the atmosphere over time. However, past investigations have shown that substantial fluctuations in atmospheric ${ }^{14} \mathrm{C}$ and in the carbon cycle do occur (BECK et al., 2001), which should be taken into account when establishing ${ }^{14} \mathrm{C}$-derived ages and corrected by means of calibration curves obtained by independent methods, such as ${ }^{230} \mathrm{Th} /{ }^{234} \mathrm{U}$ dating (BARD, 1998) or counting layers of varved (annually layered) marine sediments (HUGHEN et al., 2004).

Other challenges related to ${ }^{14} \mathrm{C}$ dating are due to the recent enrichment of the atmosphere in $\mathrm{CO}_{2}$ derived from fossil fuels, known as Suess effect. The Suess effect is related to the dilution of natural ${ }^{14} \mathrm{CO}_{2}$ concentration in the atmosphere by the additions of large amounts of fossil-fuel derived $\mathrm{CO}_{2}$, which do not contain any ${ }^{14} \mathrm{C}$. From an undisturbed pre-industrial situation two centuries ago, the $\mathrm{CO}_{2}$ concentrations in the atmosphere have increased exponentially from 280 to $380 \mathrm{ppm}$. This induces significant fluctuations of the atmospheric radiocarbon concentrations in living organisms which are in a steady-state equilibrium condition with the atmosphere. If not accounted for, the Suess effect may lead to inaccuracies in the radiocarbon dating, as some models originally assumed that the ${ }^{14} \mathrm{C} /{ }^{12} \mathrm{C}$ ratios in the atmosphere were constant over time. On the other hand, the Suess effect has been more than cancelled by the input of bomb-produced ${ }^{14} \mathrm{C}$. During the atmospheric nuclear tests, conducted mainly in the $1950 \mathrm{~s}$, enormous amounts of ${ }^{14} \mathrm{C}$ were produced, causing a global increase in the ${ }^{14} \mathrm{C}$ abundance and leading to another source of disequilibrium of ${ }^{14} \mathrm{C} /{ }^{12} \mathrm{C}$ ratios among the different carbon reservoirs (LEVIN; HESSHAIMER, 2000). However, because ${ }^{14} \mathrm{C}$ sediment dating normally involves samples older than 100 years, the input of "old" $\mathrm{CO}_{2}$ (from the Suess effect) and "new" ${ }^{14} \mathrm{C}$ (from the atomic bombs) are usually not relevant for these applications.

Radiocarbon ages of marine samples are also skewed by the reservoir effect, i.e., contemporary marine samples appear older than terrestrial samples. This happens because the ocean does not respond immediately to ${ }^{14} \mathrm{C}$ changes in the atmosphere and because ${ }^{14} \mathrm{C}$ exchange between the atmosphere and the ocean depends on the water depth and location. In general, the reservoir effect reduces the ${ }^{14} \mathrm{C}$ ages about 400 years in the upper $200 \mathrm{~m}$ layer of the oceans and deeper waters may look even older (STUIVER; BRAZIUNAS, 1993; BROECKER et al., 1995). The magnitude of this process varies spatially and temporally, especially in upwelling regions. Regional corrections should be made whenever possible. The offset caused by the reservoir effect may be determined by comparison with independent geochronology methods or by ${ }^{14} \mathrm{C}$ dating of modern material from the same environment. For example, modern benthic foraminifera were ${ }^{14} \mathrm{C}$ dated to establish the reservoir correction for a continental shelf environment off Peru (BURNETT et al., 2000).

Sedimentation Rates in Brazilian Coastal Environments

Many studies were undertaken concerning sedimentation rates in different Brazilian coastal environments in the last decade (Table 2). One may observe that the sedimentation rates obtained by different authors are often lower than $1 \mathrm{~mm}$ /year when calculated with ${ }^{14} \mathrm{C}$ and higher than $1 \mathrm{~mm} /$ year when obtained from ${ }^{210} \mathrm{~Pb}$ measurements. Although this is clearly a very general observation, this may represent a real anthropogenically-driven change in sedimentation process over the time spans covered by the two tracers $\left({ }^{210} \mathrm{~Pb} \sim 100\right.$ years; ${ }^{14} \mathrm{C} \sim 50,000$ years $)$.

In Patos Lagoon, the largest coastal lagoon in the world, the sedimentation rates determined via ${ }^{14} \mathrm{C}$ ages were comparable to the stratrigraphic projection based on the seismic record. However, ${ }^{210} \mathrm{~Pb}$-derived sedimentation rates were ten-fold higher 
(Table 2), which was interpreted as a result of deforestation in the drainage basin during the last century (TOLDO et al., 2000). Apparent discrepancies between sedimentations rates calculated with ${ }^{14} \mathrm{C}$ and ${ }^{210} \mathrm{~Pb}$ have been reported before in the literature. It may be related either to overestimation of the ${ }^{210} \mathrm{~Pb}$-derived sedimentation rate due to mixing processes or to the fact that the choice of the technique is always influenced by expected ages (i.e., the two tracers integrate over much different time scales). In addition, reporting results in length per time (mm/year) rather than mass flux $\left(\mathrm{g} / \mathrm{cm}^{2} /\right.$ year) may bias the interpretation towards high ${ }^{210} \mathrm{~Pb}$ derived ages. This happens because the density of surface sediment layers is usually lower than in deeper layers, so if this is taken into account, ${ }^{210} \mathrm{~Pb}$ - and ${ }^{14} \mathrm{C}$-derived mass accumulation rates may be more comparable. In spite of these potential problems, the temporal spans covered by the two methodologies could explain much of the differences.

Table 2. Sedimentation rates in Brazilian coastal environments. The results are presented in mm/y because most authors did not report sediment densities.

\begin{tabular}{|c|c|c|c|c|}
\hline Location & Site description & Method & $\begin{array}{l}\text { Sedimentation Rate } \\
\qquad(\mathrm{mm} / \mathrm{y})\end{array}$ & Reference \\
\hline Cabo Frio & Coastal upwelling & ${ }^{14} \mathrm{C}$ & $0.26-0.66$ & Mahiques et al., 2005 \\
\hline São Paulo bight & Outer-shelf and upper slope & ${ }^{14} \mathrm{C}$ & $0.005-0.660$ & Mahiques et al., 2004 \\
\hline Campos Basin & Southeast continental slope & ${ }^{14} \mathrm{C}$ & $0.04-0.09$ & Macario et al., 2004 \\
\hline SE continental shelf & $\begin{array}{l}\text { Close to medium-sized river } \\
\text { mouths }\end{array}$ & ${ }^{210} \mathrm{~Pb}$ & $1.3-8.1$ & Patchineelam \& Smoak, 1999 \\
\hline Patos Lagoon & Large temperate coastal lagoon & ${ }^{14} \mathrm{C}$ & 0.52 & Toldo et al., 2000 \\
\hline Patos Lagoon & Same as above & ${ }^{210} \mathrm{~Pb}$ & $3.5-8.3$ & Toldo et al., 2000 \\
\hline Guanabara Bay & $\begin{array}{l}\text { Highly eutrophicated tropical } \\
\text { estuary }\end{array}$ & ${ }^{210} \mathrm{~Pb}$ & 20 & Wiken et al., 1986 \\
\hline Guanabara Bay & Same as above & ${ }^{210} \mathrm{~Pb}$ & $3.0-9.5$ & Godoy et al., 1998b \\
\hline Guanabara Bay & Same as above & ${ }^{210} \mathrm{~Pb}$ & $6.3-10.5$ & Oliveira et al., 2005 \\
\hline Guarapina Lagoon & Non-impacted tropical lagoon & ${ }^{210} \mathrm{~Pb}$ & $2.6-1.1$ & Oliveira et al., 2005 \\
\hline Sepetiba Bay & $\begin{array}{l}\text { Highly industrialized tropical } \\
\text { embayment }\end{array}$ & ${ }^{210} \mathrm{~Pb}$ & $4.1-10.9$ & Oliveira et al., 2005 \\
\hline Sepetiba Bay & Same as above & ${ }^{210} \mathrm{~Pb}$ & $2-8$ & $\begin{array}{l}\text { Forte, } 1996 \text { cited in Molisami } \\
\text { et al. } 2004\end{array}$ \\
\hline Sepetiba Bay & Mangroves and mudflat & ${ }^{210} \mathrm{~Pb}$ & $1.2-1.8$ & $\begin{array}{l}\text { Smoak and Patchineelam, } \\
1999\end{array}$ \\
\hline Jacarepaguá Lagoon & $\begin{array}{l}\text { Tropical chocked coastal } \\
\text { lagoon }\end{array}$ & ${ }^{210} \mathrm{~Pb}$ & $4-22$ & Fernandes et al., 1993 \\
\hline Paranaguá Bay & $\begin{array}{l}\text { Mangrove-encircled, impacted } \\
\text { estuary }\end{array}$ & ${ }^{210} \mathrm{~Pb}$ & 1.2 & Souza et al., 2001 \\
\hline \multirow[t]{2}{*}{ Guaratuba Bay } & \multirow[t]{2}{*}{ Pristine estuary } & ${ }^{210} \mathrm{~Pb}$ & 6.1 & \multirow[t]{2}{*}{ Sanders et al., 2006} \\
\hline & & ${ }^{137} \mathrm{Cs}$ & 5.2 & \\
\hline Cananéia-Iguape & $\begin{array}{l}\text { Estuary receiving drainage of } \\
\text { granites }\end{array}$ & $\begin{array}{l}{ }^{210} \mathrm{~Pb} \\
{ }^{137} \mathrm{Cs}\end{array}$ & $\begin{array}{l}5.3-9.8 \\
5.5-9.1\end{array}$ & Saito et al., 2001a \\
\hline São Paulo & $\begin{array}{l}\text { Continental shelf up to } 180 \mathrm{~m} \\
\text { deep }\end{array}$ & ${ }^{210} \mathrm{~Pb}$ & $1.8-4.0$ & Saito et al., 2001b \\
\hline \multirow[t]{2}{*}{ Amazon river } & \multirow[t]{2}{*}{ High energetic estuarine area } & ${ }^{210} \mathrm{~Pb}$ & 13 & \multirow[t]{2}{*}{ Godoy et al., 1998b } \\
\hline & & ${ }^{137} \mathrm{Cs}$ & 11 & \\
\hline
\end{tabular}


The São Paulo and Rio de Janeiro coasts are the sites where most sedimentation studies have been conducted in Brazil. In the Cananéia-Iguape estuary, in the São Paulo State, the sedimentation rates were calculated from the slope of the unsupported ${ }^{210} \mathrm{~Pb}$ profile in the core as well as by using the ${ }^{137} \mathrm{Cs}$ peak as a time marker. Some authors point out that the input of ${ }^{137} \mathrm{Cs}$ in the Southern Hemisphere was quite small, thereby limiting the use of this tracer for dating purposes. However, sedimentation rates obtained by employing both ${ }^{210} \mathrm{~Pb}$ and ${ }^{137} \mathrm{Cs}$ dating methods were in good agreement in this case (SAITO et al., 2001; Fig. 2). This was also observed in Guaratuba bay, a semi-pristine estuary in Paraná State (SANDERS et al., 2006), in Paranaguá Bay harbor (SOUZA et al., 2001), and in the Amazon river estuary (GODOY et al., 1998b). Apparently, transuranics $\left({ }^{241} \mathrm{Am}\right.$ and ${ }^{239} \mathrm{Pu}$ ) have not been used as a sediment tracer in Brazil yet.

Rio de Janeiro is a State of high interest for sedimentation studies due to its high population densities and concentration of economic activities near the coast. More than 10 million people live in the Guanabara Bay basin, which shelters an important port and receives an extraordinary amount of untreated sewage. The sedimentation rates increased from 0.15 to $2.2 \mathrm{~cm} /$ year in the last 50 years due to sewage input, deforestation, river bed dredging, and soil management malpractices (WILKEN et al., 1986; GODOY et al., 1998a). When compared to nonimpacted nearby coastal environment, the sedimentation rates in Guanabara Bay are clearly higher, depicting the effect of urbanization on riverborne sediment input (FERNANDES et al., 1993; OLIVEIRA et al., 2004). This has important economical implications if one takes into account the costs of removing this sediment for navigation purposes.

Sepetiba Bay, which is a large coastal embayment in the Rio de Janeiro State, has experienced a similar phenomenon. During the past 100 years, the sediment accumulation rates increased ten-fold along the coast of this Bay (FORTE, 1996, cited in MOLISANI et al., 2004). This was explained by human-induced landscape changes. Firstly, at the beginning of the last century, straightening of rivers and the building of artificial channels were conducted to control malaria. Secondly, in the 1950's river waters were diverged from the Paraíba do Sul River to the Sepetiba Bay basin. This rose the freshwater flow from $<20$ to $160 \mathrm{~m}^{3} / \mathrm{s}$ and increased sediment fluxes into the bay. Finally, after the 1970 s, the creation of an industrial district and population growth resulted in extensive deforestation of the basin, increased erosion, and led to a further increase in sedimentation rates (Fig. 3). These dramatic observations probably represent a large-scale pattern for many similar coastal ecosystems and point to the need of analogous investigations in other environments. It is expected that the planned dredging and expansion of Sepetiba harbor will further augment the processes of sedimentation (MOLISANI et al., 2004). Therefore, ${ }^{210} \mathrm{~Pb}$-derived sedimentation rates are useful for planning and managing this kind of activity. In order to do that, it is important that the models applied are as reliable as possible. As stated earlier, sediment mixing by physical or biological processes is a key process that should be considered when calculating ${ }^{210} \mathrm{~Pb}$ sedimentation rates, since it can affect the ${ }^{210} \mathrm{~Pb}$ profile and lead to incorrect sedimentation rate interpretations.

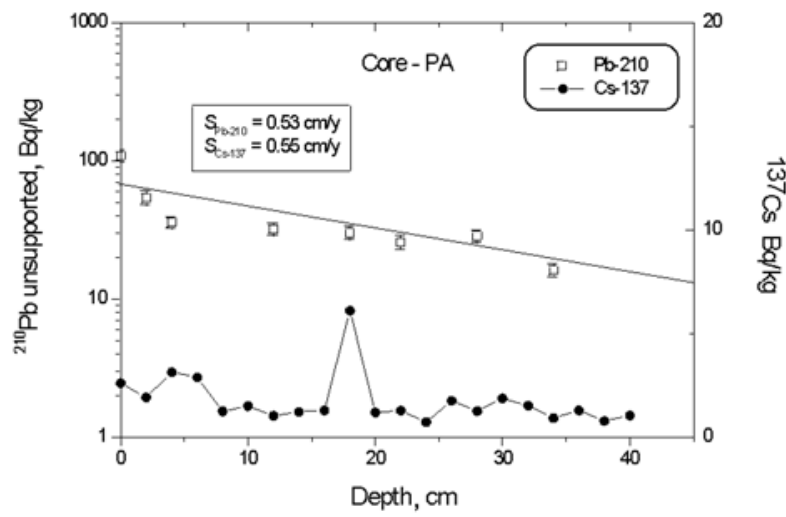

Fig. 2. Unsupported ${ }^{210} \mathrm{~Pb}$ and ${ }^{137} \mathrm{Cs}$ levels in a sediment core of CananéiaIguape estuary. The results show a good agreement between ${ }^{210} \mathrm{~Pb}$ - and ${ }^{137} \mathrm{Cs}$-derived sedimentation rates (SAITO et al., 2001). 


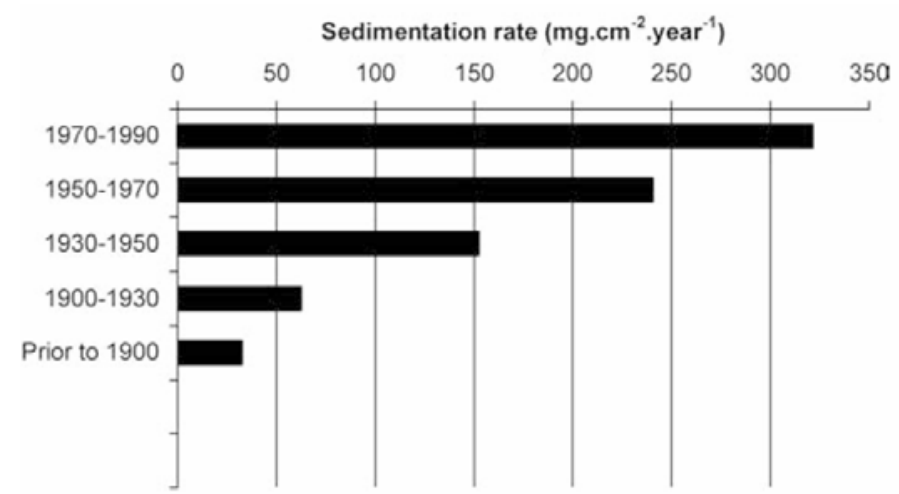

Fig. 3. Sedimentation rates estimated for the Eastern Sepetiba Bay coast (FORTE, 1996, cited in MOLISANI et al., 2004). The results indicated an increase in sedimentation processes due to anthropogenic activities.

Smoak and Patchineelam (1999) elegantly addressed the sediment mixing issue in Sepetiba Bay by measuring the particle-reactive isotopes ${ }^{234} \mathrm{Th}$ and ${ }^{7} \mathrm{Be}$. The fact that these isotopes are produced either in seawater from dissolved ${ }^{238} \mathrm{U}\left({ }^{234} \mathrm{Th}\right)$ or in the atmosphere by cosmic rays $\left({ }^{7} \mathrm{Be}\right)$ associated with their short half lives (Table 1) indicates that their occurrence in below-surface sediment layers is usually best explained by mixing processes (or very rapid accumulation). The analysis of ${ }^{234} \mathrm{Th}$ and ${ }^{7} \mathrm{Be}$ distributions in Sepetiba Bay sediments indicated that the mixed layer depths ranged from $4 \mathrm{~cm}$ (in mangroves protected by vegetation) to $30 \mathrm{~cm}$ (in a mud flat highly disturbed by particle remobilization). Once a sediment mixed layer has been identified, it is possible to reliably calculate sedimentation rates below the mixed layer (SMOAK; PATCHINEELAM, 1999).

The problem of sedimentation in Sepetiba Bay has been investigated from multiple approaches. It has been suggested that the ${ }^{210} \mathrm{~Pb}$-derived geochronology can be validated by interpreting heavy metal profiles and lead stable isotopes. Since human interventions in Sepetiba Bay watershed are well documented, the changes in heavy metal profiles may be reliably related to those interventions. The results of such an exercise indicated that ages derived neither from CIC nor CRS models agreed with the history of regional industrialization (MARQUES JR. et al., 2006). These authors inferred that this disagreement is caused by the evolution of the system, i.e., mangrove accretion made the sediment sources change from lateral transport to a smoother runoff from the nearby banks. The particles originating from the surface of banks would be relatively richer in atmospheric ${ }^{210} \mathrm{~Pb}$. By assuming initial ${ }^{210} \mathrm{~Pb}$ concentration increased over time, the ${ }^{210} \mathrm{~Pb}$ chronologies did agree well with the heavy metal profiles. At sites where ${ }^{210} \mathrm{~Pb}$ dating is accompanied by determination of trace metals or other contaminants, one can also investigate possible mechanisms driving contaminant accumulation and relate such processes to historic events, as conducted by a few Brazilian investigators (FERNANDES et al., 1993; GODOY et al., 1998). For example, a 2-fold increase in ${ }^{210} \mathrm{~Pb}$-derived mercury fluxes into Guaratuba Bay sediments was suggested to be related to increasing agriculture in its basin (SANDERS et al., 2006).

Although most sedimentation studies in Brazil have been carried out in estuaries, some of them focused on continental shelf sediments. The western tropical South Atlantic margin is characterized by the oligotrophic, nutrient-poor waters of the Brazil Current and the North Brazil Current, as well as by little fluvial terrigenous input. This leads to a general scenario of very low sedimentation rates (MAHIQUES et al., 2005). As a consequence, sedimentation rates correlate with shelf slope morphology and the meandering pattern of the Brazilian current. The onshore flows of the Brazilian Current are places of lower sedimentation in comparison to the offshore flows (MAHIQUES et al., 2002).

Upwelling zones, such as the Cabo Frio upwelling system in the Rio de Janeiro coast, are typically considered areas of high sedimentation (Table 2). The temporal sedimentation changes observed in Cabo Frio are explained by natural variability in the trade winds and Brazil current meandering patterns (MAHIQUES et al., 2005). In the São Paulo Bight, there is a north-south gradient separated by São Sebastião Island. The southern sector is more influenced by colder, nutrient-richer waters, whereas the northern sector is basically influenced by Brazil Current waters. The higher sedimentation rate areas correlate positively with pelagic primary productivity and organic carbon 
content in sediments, indicating that the sedimentation in the SE Brazil upper margin is controlled by the pelagic processes associated with the northward propagation of cold waters (MAHIQUES et al., 2004).

The analysis of ${ }^{210} \mathrm{~Pb}$ in box cores collected close to river mouths along the eastern Brazilian shelf (water depths of $10-30 \mathrm{~m}$ ) also revealed that the sedimentation rates are strongly influenced by current patterns and seabed morphology. The highest values $(8.1 \mathrm{~mm} /$ year) were found in a sheltered channel near the Caravelas Bank, probably as a result of sediment transport from the Bank (PATCHINEELAM; SMOAK, 1999). On the continental slope, the sedimentation processes are strongly influenced by the continental climate and ${ }^{14} \mathrm{C}$-derived sedimentation rates do not exceed $1 \mathrm{~mm} / \mathrm{yr}$ (KNOPPERS et al., 1999; MACARIO et al., 2004), values significantly lower than on the continental shelf (Table 2).

Even though the results summarized in Table 2 provide insights into the order of magnitude of sedimentation rates in some Brazilian coastal environments, we have not gathered enough information yet to extrapolate to the different climatic/geomorphologic sectors of the Brazilian coast, as summarized in Figure 1. For example, we were unable to find any publication focusing on sedimentation rates between the $\sim 1^{\circ}$ and $15^{\circ} \mathrm{S}$ latitudes (from south Bahia to Pará State), covering most of the dry, low productivity NE Brazilian coast. We can speculate, however, that high sedimentation rates will usually be associated with high productivity regions (such as the southern and north Brazilian shelf and upwelling areas). Estuaries draining wet, high relief areas and where the natural vegetation has been cleared should also be associated with high sedimentation rates. Low or decreasing sedimentation rates, may be expected to be found on the shelf off preserved estuaries surrounded by marshes and/or mangroves and off dammed rivers, such as the São Francisco and Paraíba do Sul Rivers, as such areas trap sediments efficiently. Considering the diversity and complexity of the Brazilian coast, we suggest that future investigations determine sedimentation rates across climatic gradients.

\section{Submarine Ground Water Discharge}

Although it is not as obvious as surface flows, the input of water and dissolved species to the oceans through groundwater is also important. The investigation of submarine groundwater discharge (SGD) via natural radioisotopes is still an emerging field; the first papers relevant to U/Th nuclides on this subject were published just one decade ago (CABLE et al., 1996; MOORE, 1996). Globally, fresh SGD has been estimated to be a few percent of the total water flux to the oceans, but regionally the total groundwater flux (including recirculated seawater) may be much higher, as observed in the Yellow Sea (KIM et al., 2005) and some volcanic islands (KIM et al., 2003; BURNETT et al., 2006). Because nutrient concentrations in groundwater are usually more than one order of magnitude higher than surface water, it has been suggested that SGD plays a significant role in coastal biogeochemistry (BURNETT et al., 2003). This is thus a significant process when an aquifer and the ocean are connected through permeable sediments. Its relative importance depends on several variables, such as the anthropogenic enrichment, recharge through rainfall, tidal range, and the permeability of aquifer sediments (CHARETTE et al., 2003).

Basically, there are three approaches for measuring SGD, e.g., modeling, direct measurements and geochemical tracers. A promising approach is the utilization of radioisotopes as natural geochemical tracers, taking into account that the water column integrates natural tracers coming into the system through groundwater, minimizing small-scale effects (BURNETT et al., 2006). In the last decade, many studies were carried out using radioisotopes of Ra and $\mathrm{Rn}$ to understand SGD patterns in the coastal zone. These isotopes have a wide range of half-lives and can be used for identifying input rates on different time scales. While radium isotopes trace the saline portion of SGD, ${ }^{222} \mathrm{Rn}$ traces the total SGD (fresh + recirculated seawater). Therefore, a multiple tracer approach is preferred to understand SGD dynamics (DULAIOVA et al., 2006). In the next sections, we will depict the basic principles of ${ }^{222} \mathrm{Rn}$ and radium isotopes use as SGD tracers and discuss the available examples of their application in Brazil.

\section{Use of ${ }^{222} \mathrm{Rn}$ and $\mathrm{Ra}$ Isotopes as Tracers of SGD}

Radon-222 is an excellent natural tracer for identifying SGD into near shore coastal ecosystems because its half-life is comparable to the time scale of most coastal process, it is $2-4$ orders of magnitude more concentrated in groundwater than seawater, and it is conservative (i.e., concentrations are not influenced by biological and/or chemical processes). A complete description of the calculations and corrections required for estimating SGD based on radon measurements has been recently published (BURNETT; DULAIOVA, 2003), but it is simplified in Figure 4 and in the following equation:

$$
\frac{d I}{d t}=J-F_{m i x}-F_{a t m}-I \lambda
$$

where I represents the ${ }^{222} \mathrm{Rn}$ total inventory in the water column, $\mathrm{J}$ is the total influx, $\mathrm{F}_{\text {mix }}$ is the loss seaward, $F_{\text {atm }}$ is the loss to atmosphere, and $I \lambda$ is the decay term. 


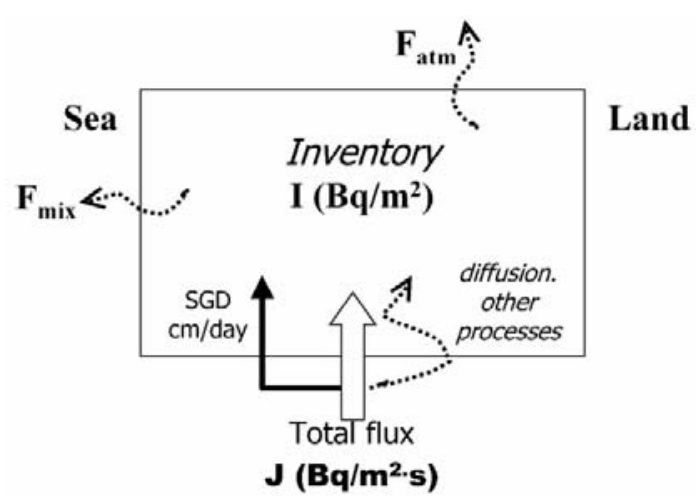

Fig. 4. Conceptual model of use of radon for estimating submarine groundwater discharge into the coastal zone. The inventory refers to the total amount of excess ${ }^{222} \mathrm{Rn}$ per unit area. Decay is usually neglected because the fluxes are evaluated on a very short (1-2 hours) time scale relative to the half-life of ${ }^{222} \mathrm{Rn}$ (BURNETT; DULAIOVA, 2003).

Equation (3) states that the temporal variability of the total inventory of ${ }^{222} \mathrm{Rn}$ in the water column must be balanced by the difference between its total inputs and total losses. All terms in this equation are usually directly measured or estimated, except $\mathrm{J}$. So the solution of (3) for J provides the total ${ }^{222} \mathrm{Rn}$ influx into the water column. Assuming that benthic fluxes of radon are driven mainly by groundwater inputs, one can convert calculated ${ }^{222} \mathrm{Rn}$ fluxes to water fluxes by dividing the estimated total ${ }^{222} \mathrm{Rn}$ fluxes by the measured or estimated radon concentration in groundwater.

The general assumption of this model (groundwater advective transport is the main source of radon) appears to be satisfied in most situations where the model has been applied. A second source is the ${ }^{222} \mathrm{Rn}$ ingrowth from ${ }^{226} \mathrm{Ra}$ decay in the water column, but it can be easily measured and appropriate corrections made. Another possible source at the sediment water-interface is diffusion. This may be measured through many methods (CORBETT et al., 1998) and results have indicated that in permeable sediments diffusion is negligible in comparison to advection. The ${ }^{222} \mathrm{Rn}$ concentrations in surface water and groundwater may be assessed using continuous radon monitors, which provide high temporal resolution of ${ }^{222} \mathrm{Rn}$ measurements (DULAIOVA et al., 2005).

As well as ${ }^{222} \mathrm{Rn}$, radium isotopes are effective tracers of SGD as they behave conservatively in seawater and groundwater provides the primary source of Ra to many coastal waters. The activities of $\mathrm{Ra}$ in saline groundwater are typically 1 to 3 orders of magnitude higher than surface waters. An advantage of radium is that it has four isotopes with a range of half-lives from 3.7 days to 1600 years (Table 1), making them a powerful "quartet" for estimating water residence times and quantifying SGD. All derive from decay of Th parents which are tightly bound to particles. Once Th isotopes decay, radium isotopes are quickly mobilized because they are soluble in saline water. Sediments thus provide a continuous source of $\mathrm{Ra}$ isotopes to coastal waters at rates set by their decay constants (Moore, 1996; Rama and Moore, 1996).

The principle of the approach for determining SGD fluxes from $\mathrm{Ra}$ isotopes is similar to that employed for ${ }^{222} \mathrm{Rn}$. The long-lived $\mathrm{Ra}$ isotopes $\left({ }^{226} \mathrm{Ra}\right.$ and $\left.{ }^{228} \mathrm{Ra}\right)$ removal from a particular system must be balanced by equivalent inputs in a steady state system. Corrections for atmosphere losses are not necessary because $\mathrm{Ra}$ is not a gas. The technique is based on the differences in half-life (and hence regeneration times) of the $\mathrm{Ra}$ isotopes from their thorium parents. If the radium concentrations in groundwater, the offshore gradient, and residence times can be established, the flux of radium and therefore SGD can be quantified. It has been shown that long-lived $\mathrm{Ra}$ isotope activity gradients in coastal sediments are low, therefore diffusion is also usually negligible in comparison to advective flows (RAMA; MOORE, 1996).

\section{SGD Studies in Brazil}

One factor that does not allow an accurate assessment of the importance of groundwater discharge on a global scale is the limited number of regional studies in key areas of developing countries with increasing population densities and fertilizer usage. A pioneer study in Brazil was conducted by Oliveira et al. (2003). They estimated SGD in a series of small tropical coastal embayments of Ubatuba, São Paulo. After measuring ${ }^{222} \mathrm{Rn}$ and its parent ${ }^{226} \mathrm{Ra}$ activities in seawater vertical profiles and sediments they could estimate SGD (Fig. 5) following the basic approach described above. The overall groundwater discharge necessary to balance the excess ${ }^{222} \mathrm{Rn}$ inventory for one area in Flamengo Bay was estimated to be $23 \pm 22 \mathrm{~cm} /$ day. In spite of the high variability, the values were in agreement with the ones estimated by seepage meters $(1.4-21.6 \mathrm{~cm} /$ day $)$, which is a direct measurement technique. The high variability is characteristic of this kind of process, since the water influx is very dynamic, often influenced by the tidal cycle (OLIVEIRA et al., 2003). Later on, seasonal investigations showed that highest excess ${ }^{222} \mathrm{Rn}$ inventories coincide with the month of highest precipitation (March), indicating that rainfall is the main regional SGD driver (OLIVEIRA et al., 2006). Radium has been qualitatively used as a SGD tracer in this area (GODOY et al., 2006). 


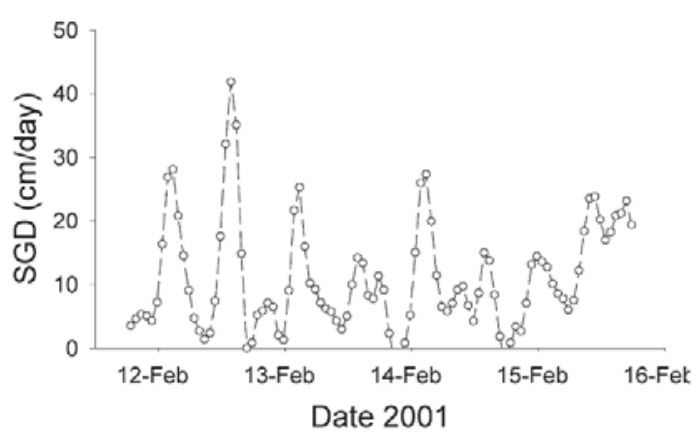

Fig. 5. SGD rates based on the continuous ${ }^{222} \mathrm{Rn}$ measurements in Ubatuba (OLIVEIRA et al., 2003). The results show a semi-diurnal variability, probably influenced by tidal pumping.

The most extensive SGD investigation in Brazil was carried out in Ubatuba again (November 2003) during the joint UNESCO/IAEA intercomparison experiment (BURNETT et al., 2006). These experiments were conducted in five environmental settings around the world and showed that the different techniques (radioactive tracers, seepage meter, modeling, and artificial tracers) used to determine SGD provide complementary information and have their own advantages and disadvantages. In Ubatuba, the irregular spatial distribution of SGD seemed to be a characteristic of fractured rock aquifers.

Another series of SGD investigations was conducted in the barrier spit that separates the Patos Lagoon from the Atlantic Ocean, in the Rio Grande do Sul State (WINDOM; NIENCHESKI, 2003). Even though these authors have not used isotopes as a tool, they showed that freshwater flows through the permeable sand sediments and mixes with seawater in a biogeochemically-active area. More recently, they analyzed samples of fluids (pore water along the beach) that supply elements to the coastal waters and $\mathrm{Ra}$ isotopes in transects perpendicular to the coastline. The short-lived radium isotopes $\left({ }^{223} \mathrm{Ra}\right.$ and $\left.{ }^{224} \mathrm{Ra}\right)$ were used to constrain the residence time and offshore mixing of water on the shelf. Models based on crossshelf dispersion and water mass ages agreed on a 7-8 day residence time. The results indicated high fluxes of SGD and suggest that the chemistry of the shelf waters is strongly affected by SGD containing high concentrations of nutrients ( $, \mathrm{P}, \mathrm{Si}$ and $\mathrm{Fe})$. These investigations suggested that the SGD-derived inputs of nutrients support the high biological productivity in the region (MOORE, 2006; WINDOM et al., 2006).

\section{Anthropogenic Radionuclide Contamination}

Atmospheric nuclear test explosions in the mid $20^{\text {th }}$ century contaminated the Earth globally with radioactive debris in great quantities. Accidents in nuclear power plants, aircrafts, submarines, and nuclear-powered satellites are also sources of radioactive contamination. The oceans may receive radioactive fallout directly from the atmosphere; indirectly as run-off from land; and as liquid waste or dumped as solid waste. Reported ocean dumping was carried out in the western world from the late 1940s to the middle of the 1960s, mainly in the North Atlantic and Pacific Oceans (AARKROG, 1998; AARKROG, 2003).

There are more than 200 radionuclides that may affect human and environmental health. However, few have been considered important (e.g., ${ }^{137} \mathrm{Cs},{ }^{90} \mathrm{Sr},{ }^{238} \mathrm{Pu}$ and ${ }^{239+240} \mathrm{Pu}$ ) due to their higher production and relatively long half-lives. The radionuclides ${ }^{137} \mathrm{Cs}$ and ${ }^{90} \mathrm{Sr}$ are the main contributors to the present radiation doses from man-made sources in the environment (AARKROG, 2003) and are particularly important because they may be related to $\mathrm{K}$ and $\mathrm{Ca}$ distribution in biological processes, being accumulated in muscles and in skeleton tissues, respectively (AKHTER et al., 2004).

In spite of contamination problems in many ecosystems in northern hemisphere, the studies conducted along the Brazilian coast have shown negligible human-produced radionuclide pollution. Table 3 shows artificial radionuclide concentrations in seawater, sediments, and fish from Brazilian coastal areas. The baseline ${ }^{137} \mathrm{Cs},{ }^{90} \mathrm{Sr},{ }^{239+240} \mathrm{Pu}$, and ${ }^{238} \mathrm{Pu}$ concentrations in seawater from the whole Brazilian coast are very low and are always much lower than areas influenced by inputs from discharge of nuclear plants or the Chernobyl accident. The concentration levels of these anthropogenic nuclides in the water column can be explained by global fallout and therefore there are no signs of dumping of radioactive wastes (CUNHA; FABRA, 1995; FIGUEIRA; CUNHA, 1995a; FIGUEIRA; CUNHA, 1995b; FIGUEIRA; CUNHA, 1998; CUNHA et al., 1999; FIGUEIRA et al., 2001; GODOY et al., 2003; FIGUEIRA et al., 2006). Additionally, the low anthropogenic radionuclide activities along the Brazilian coast is related to low inter-hemispheric atmospheric transport. Even though two thirds of the ${ }^{137}$ Cs released by the Chernobyl accident in 1986 were deposited outside the former Soviet Union, the values for the northern hemisphere are about three times higher than in the southern hemisphere (AARKROG, 1998).

Although the ocean contains most of the anthropogenic radioactivity $(\sim 60 \%$ of the global fallout), the radiological impact of this contamination is low. Radiation doses from naturally-occurring nuclides in the marine environment (e.g. ${ }^{210} \mathrm{Po}$ ) have been considered two orders of magnitude higher than radiation from artificial radionuclides (AARKROG et 
al., 1997). This is also true for Brazil, where the activities of ${ }^{137} \mathrm{Cs}$ in the Corvine Micropogonia furnieri (mean $0.3 \mathrm{~Bq} / \mathrm{kg}$ ) (CUNHA et al., 1993) were much lower than those of the naturally occurring ${ }^{210} \mathrm{Po}$ (mean of $3.2 \mathrm{~Bq} / \mathrm{kg}$ ) (MOREIRA et al., 2002). Relatively high ${ }^{210} \mathrm{Po}$ concentrations were also determined in crustaceans and mollusks of CananéiaIguape estuary (SAITO; CUNHA, 2003) and in the filter-feeding bivalve Perna perna along the Rio de Janeiro coast (GOUVEA et al., 1987). These ${ }^{210} \mathrm{Po}$ activities are naturally elevated and consistent with those found elsewhere.

The main pathway leading to human exposure from the occurrence of anthropogenic nuclides in the marine environment is due to consumption of seafood. However, analysis of ${ }^{137} \mathrm{Cs}$ in five fish species from the coast of São Paulo indicated a negligible input of this nuclide to humans via fish consumption. The annual dose of ${ }^{137} \mathrm{Cs}$ was estimated to be two orders of magnitude lower than the upper limits recommended by the International Atomic Energy Agency (CUNHA et al., 1993). Analysis of ${ }^{90} \mathrm{Sr}$ in bones and muscles of coastal fish also indicated negligible radiological concern (FIGUEIRA; CUNHA, 1995a).

The results obtained in Brazil are not surprising. In fact, the radiological impact of marine radioactivity is low compared with that of radioactivity in the terrestrial environment. Doses from anthropogenic radionuclides in the marine environment are generally one to two orders of magnitude lower than doses from such nuclides on land (AARKROG, 1998). This is true specifically for Brazil, where the levels are among the lowest reported anywhere. However, it does not mean that monitoring of nuclides in areas of high interest, such as near nuclear plants, is not recommended. Additionally, determination of residence time of nuclides in the surface layer of the oceans, where most fishing occurs, is also necessary.

\section{High Natural Radioactivity Areas And Tenorm Wastes}

Some of the most important areas of high natural radioactivity (HINAR) in the world are located along or near the Brazilian coastal zone. For example, the Serra do Mar geological formation is located near the coast in southeastern Brazil. The most abundant rocks of this formation are granites and gneisses. Taking into account that both ${ }^{232} \mathrm{Th}$ and ${ }^{238} \mathrm{U}$ concentrations are high in its felsic, acidic rocks, the Serra do Mar formation is a source of radionucliderich minerals to nearby coastal environments. In this area, ${ }^{222} \mathrm{Rn}$ concentrations in groundwater are usually high (GODOY; GODOY, 2006). As a result of rock weathering and erosion, sedimentary deposits of radioactive heavy minerals occur widespread along the coast of Espírito Santo and Rio de Janeiro States, extending from latitude $22^{\circ} 30^{\prime}$ to $15^{\circ} 45^{\prime} \mathrm{S}$. The main heavy minerals are iron oxides (ilmenite and magnetite), zirconium silicates (zirconite), and rare earth phosphates with $4-6 \%$ of thorium impurities (monazite) (PASCHOA, 2000).

Table 3. Human-produced radionuclide concentrations in seawater, fish and sediment from the Brazilian coast.

\begin{tabular}{llcccl}
\hline Nuclide & Local & Sampling Year & Matrice & Concentration & Reference \\
\hline${ }^{137} \mathrm{Cs}$ & São Paulo Coast & - & Fish & $0.1-0.3 \mathrm{~Bq} / \mathrm{kg}$ & Cunha et al., 1993 \\
& Southeastern Shelf & $1997-2002$ & Fish & $<1.6 \mathrm{~Bq} / \mathrm{kg}$ & Godoy et al., 2003 \\
& Whole Brazilian Coast & $1992-1994$ & Fish & $0.01-0.22 \mathrm{~Bq} / \mathrm{kg}$ & Cunha et al., 1999 \\
& São Paulo Coast & - & Seawater & $1.7-1.9 \mathrm{~Bq} / \mathrm{m}^{3}$ & Cunha et al., 1993 \\
& Southeastern Shelf & $1997-2002$ & Seawater & $0.9-4.0 \mathrm{~Bq} / \mathrm{m}^{3}$ & Godoy et al., 2003 \\
& Whole Brazilian Coast & $1992-1994$ & Seawater & $0.8-1.7 \mathrm{~Bq} / \mathrm{m}^{3}$ & Cunha et al., 1999 \\
& Southern Coast & - & Seawater & $0.1-4.7 \mathrm{~Bq} / \mathrm{m}^{3}$ & Figueira et al., 2001 \\
& Whole Brazilian Coast & $1992-1994$ & Sediment & $0.4-1.8 \mathrm{~Bq} / \mathrm{kg}$ & Cunha et al., 1999 \\
& Southeastern Shelf & $1997-2002$ & Sediment & $0.3-3.8 \mathrm{~Bq} / \mathrm{kg}$ & Godoy et al., 2003 \\
& Southeastern Shelf & 1997 & Sediment & $0.3-1.8 \mathrm{~Bq} / \mathrm{kg}$ & Figueira et al., 2006 \\
\hline${ }^{90} \mathrm{Sr}$ & Whole Brazilian Coast & $1992-1994$ & Sediment & $<0.8 \mathrm{~Bq} / \mathrm{Kg}$ & Cunha et al., 1999 \\
& São Paulo Shelf & 1993 & Seawater & $1.6 \mathrm{~Bq} / \mathrm{m}^{3}$ & Figueira and Cunha, 1995b \\
& Whole Brazilian Coast & $1992-1994$ & Seawater & $1.8 \mathrm{~Bq} / \mathrm{m}^{3}$ & Cunha et al., 1999 \\
& Southern Coast & - & Seawater & $2.0-8.6 \mathrm{~Bq} / \mathrm{m}^{3}$ & Figueira et al., 2001 \\
& Whole Brazilian Coast & $1992-1994$ & Fish ash & $8-42 \mathrm{~Bq} / \mathrm{kg}$ & Figueira and Cunha, 1995a \\
& Southeastern Shelf & & Fish & $<0.18 \mathrm{~Bq} / \mathrm{kg}$ & Godoy et al., 2003 \\
\hline${ }^{238} \mathrm{Pu}$ & Southern Coast & - & Seawater & $1.9 \mathrm{mBq} / \mathrm{m}^{3}$ & Figueira et al., 2001 \\
& Southeastern Shelf & 1997 & Sediment & $15-150 \mathrm{mBq} / \mathrm{kg}$ & Figueira et al., 2006 \\
\hline${ }^{239+240} \mathrm{Pu}$ & Whole Brazilian Coast & $1992-1994$ & Sediment & $0.03-0.18 \mathrm{~Bq} / \mathrm{kg}$ & Cunha et al., 1999 \\
& Southern Coast & - & Seawater & $1.3-13.0 \mathrm{mBq} / \mathrm{m}^{3}$ & Figueira et al., 2001 \\
& Southeastern Shelf & 1997 & Sediment & $18-117 \mathrm{mBq} / \mathrm{kg}$ & Figueira et al., 2006 \\
\hline
\end{tabular}


The beach sands of Guarapari County (Espírito Santo State) have external radiation levels ranging between 0.4 and $0.9 \mu \mathrm{Sv}$ per hour. This is probably the highest level of radiation reported for Brazilian beaches, corresponding to 20-30 times the non-elevated natural background (ROSER; CULLEN, 1962 cited in PASCHOA, 2000). The ilmenite- and monazite-rich sands of Guarapari have attracted tourists because of their supposed therapeutic properties. The sands of the Espírito Santo State are also a source of $\mathrm{Ra}$ and other elements to coastal waters. The Buena Lagoon, for example, is enriched in dissolved $\mathrm{Ra}$ due to monazite leaching from high salinity, low $\mathrm{pH}$ groundwater seepage. This process may lead to health problems for local people who use groundwater (LAURIA; GODOY, 2002; GODOY; GODOY, 2006).

There are many other beaches in the monazite sand sedimentation zone, but few studies addressed reference radiation levels on the Brazilian coast. Along the Holocene coastal barrier of southern Brazil, for instance, the average heavy mineral content is high (4.7\%) (SILVA, 1979; DILLENBURG et al., 2004), but radiation levels have not been measured. Recently, the background radiation of Ilha Grande beach sediments (Rio de Janeiro State) was determined. It is felt that the risk of radioactive material being released to this environment is high due to the proximity of a nuclear complex. The highest natural activities were found in Preta Beach sand sediments, where average ${ }^{232} \mathrm{Th}$ and ${ }^{238} \mathrm{U}$ were 239 and $121 \mathrm{~Bq} / \mathrm{kg}$, respectively. These values are 9.5 and 4.8 times higher than the world's average in surface soils. In spite of the relatively high radiation levels, the beaches are not considered to be a radiological hazard for the local population (FREITAS; ALENCAR, 2004; ALENCAR; FREITAS, 2005).

Radiological hazards along the Brazilian coast may be important only where and when human activities have increased the potential risk for radiation exposure in comparison to the unaltered situation. In last few years, much attention has been given to Technologically Enhanced Naturally Occurring Radioactive Materials (TENORM) (BETTI et al., 2004). In Brazil, the main TENORM-producing industries are phosphate fertilizer manufactures, petroleum processing facilities, coal mining, and $U$ and Th bearing mineral extraction (FERNANDES et al., 2002; PASCHOA; GODOY, 2002). Coal, U, and Th mining do not pose significant threats to Brazilian coastal environments, but petroleum and fertilizer industries apparently do so.

Petroleum formation water typically has high salt and naturally elevated $\mathrm{Ra}$ concentrations. When this water is mixed with seawater during petroleum exploration, $\mathrm{Ra}$ is co-precipitated with barium sulfate. There are about 8000 pipes with radioactive scales and hundreds of barrels containing a mixture of oil and Ra-enriched sludge disposed by oil companies on its coastal facilities in Rio de Janeiro. Although high Ra content has been observed in these scale and sludge samples, leaching tests indicated that $\mathrm{Ra}$ is present in an insoluble barium sulfate phase, which is quite favorable from the waste management point of view (MATTA et al., 2002; GODOY; CRUZ, 2003; GAZINEU et al., 2005). Additionally, during the petroleum extraction large amounts of ${ }^{210} \mathrm{~Pb}$ are accumulated in tubes and tanks, probably associated with both sulfide and carbonate precipitation (GODOY et al., 2005).

Fertilizer industries may also be an important source of TENORM wastes to the coastal zone. During the production of phosphate fertilizers, large amounts (69 million tons in Brazil) of byproducts (phosphogypsum) are stockpiled. The U concentration in the rock used as raw material for phosphate fertilizer manufacturing is up to 100 times higher than in the average world soil. Additionally, many radioactive elements $(\mathrm{Ra}, \mathrm{Pb}, \mathrm{Po}$, and $\mathrm{Th})$ are heavily enriched in the phosphogypsum during the manufacturing process (MAZZILLI et al., 2000; SANTOS et al., 2002; SAUEIA et al., 2005; SAUEIA; MAZZILLI, 2006; SILVA et al., 2006). The magnitude and significance of phosphogypsum leaching to coastal environments are still unclear, but recent studies indicate that the higher values of $U$ and Th series nuclides in sediments of Santos harbor were observed in the vicinity of a phosphogypsum pile (SILVA et al., 2005; SILVA et al., 2006). Groundwater contamination nearby phosphogypsum piles has also been reported (SANTOS et al., 2006). Even though some attempts have been made to evaluate the radiological effects of petroleum and fertilizer industries, the studies cited above clearly show their potential threats and, therefore, it is strongly recommended to control the radiological content of their wastes.

\section{Final Remarks}

We reviewed environmental radioactivity studies along the Brazilian coast from a radiological and environmental functioning perspective. While the interpretation of radionuclide distribution may provide insights into processes different from those discussed here, such processes have not yet been investigated in much detail in Brazil. This review showed that the number of environmental radioactivity studies in Brazil is still small and much more research is needed to understand processes of high interest for environmental managers, such as sedimentation rates and SGD. 
The main conclusion of the studies about sedimentation rates in Brazilian coastal environments is that inappropriate soil mobilization by urban and agricultural activities has intensified erosion processes on land, which is reflected in depositional environments, such as coastal lagoons, estuaries and mangroves. These are the preferential environments for sediment accumulation because they are areas of low gradient, receive large loads of sediments, and flocculation is favored at the freshwater-seawater interface. On the continental shelf, higher sedimentation rates occur in upwelling areas, near river mouths, and in areas of high biological productivity.

The interpretation of ${ }^{210} \mathrm{~Pb}$-derived sedimentation rates has provided valuable information for environmental managers in restricted sectors of the Brazilian coast (e.g., mainly along the Rio de Janeiro coast). However, the comprehension of sedimentary processes is still relatively poor in Brazil. This is true not only on the continental shelf, but also in highly urbanized coastal environments. It is expected that higher sedimentation rates may be related to serious environmental, social and economic problems. Mangrove environments are particularly sensitive to such changes because vegetation accelerates the sediment accumulation rate.

Of the processes discussed in this paper, submarine groundwater discharge is the one that requires most scientific effort in the short-term. There have been only two case studies in Brazil (Ubatuba and Patos Lagoon). These indicated high groundwater flows and showed that SGD can be a major source of elements to the coastal ocean. This suggests important biogeochemical implications and the need for further studies in this emerging field. One of the main limitations of Brazilian chemical oceanography is a poor understanding of nutrient and elemental flows at the land-sea interface (NIENCHESKI et al., 1999). Thus, it is important that future nutrient budget studies consider not only river inputs, but also groundwater discharge. Additionally, taking into account that the terrestrial component of groundwater is more likely to transport pollutants, it is fundamental to determine its relative contribution. This may be quantified, for example, through simultaneous ${ }^{222} \mathrm{Rn}$ and $\mathrm{Ra}$ isotope determinations.

A large portion of the environmental radioactivity studies conducted on the Brazilian coast determined baseline values of different human-derived radionuclides. The conclusion of all these studies is that anthropogenic radioisotope contamination is negligible. The lack of observable impacts and the predictability of nuclide concentration on the Brazilian coast indicate that future studies should be conducted in areas of high interest (e.g., near nuclear facilities) and might be better focused on nuclide as tracers of environmental processes. In order to do that, it is critical that significant investments be made both in training and facilities, especially in areas where fewer or none studies have been conducted, e.g., along the north and northeast coast. In the near future, it is likely that environmental radioactivity studies in Brazil will move from descriptive, environmental quality-based assessments to approaches that attempt to quantify chemical, physical, and biological processes in the environment.

\section{ACKNOWLEDGEMENTS}

Isaac R. Santos holds a CAPES/Fulbright fellowship (2150/04-2). Many thanks to Emmanoel Silva-Filho and Sambasiva Patchineelam for introducing the topic to IRS.

\section{REFERENCES}

AARKROG, A. A retrospect of anthropogenic radioactivity in the global marine environment. Radiat. Protection Dosimetry, v. 75, n. 1-4, p. 23-31, 1998.

AARKROG, A. Input of anthropogenic radionuclides into the World Ocean. Deep- Sea Res., Part II: Topical Studies in Oceanography, v. 50, n. 17-21, p. 2597-2606, 2003.

AARKROG, A.; BAXTER, M.S.; BETTENCOURT, A.O.; BOJANOWSKI, R.; BOLOGA, A.; CHARMASSON, S.; CUNHA, I.; DELFANTI, R. et al. A comparison of doses from ${ }^{137} \mathrm{Cs}$ and ${ }^{210} \mathrm{Po}$ in marine food: A major international study. J. Environ. Radioactivity, v. 34, n. 1, p. 69-90, 1997.

ABRIL, J. M. Constraints on the use of ${ }^{137} \mathrm{Cs}$ as a timemarker to support CRS and SIT chronologies. Environ. Pollut., v. 129, p. 31-37, 2003.

AKHTER, P.; BALOCH, N.Z.; MOHAMMAD, D.; ORFI, S.D.; AHMAD, N. Assessment of strontium and calcium levels in Pakistani diet. J. Environ. Radioactivity, v.73, n. 3, p. 247-256, 2004.

ALENCAR, A.S. ; FREITAS, A.C. Reference levels of natural radioactivity for the beach sands in a Brazilian southeastern coastal region. Radiat. Measurements, v. 40, n.1, p. 76-83, 2005.

APPLEBY, P. G.; OLDFIELD, F. The assessment of ${ }^{210} \mathrm{~Pb}$ data from sites with varying sediment accumulation rates. Hydrobiologia, v. 103, p.29-35, 1983.

BARD, E. Geochemical and geophysical implications of the radiocarbon calibration. Geochimica Cosmochim. Acta., v. 62, n. 12, p. 2025-2038, 1998.

BECK, J. W.; RICHARDS, D. A.; EDWARDS, R. L.; SILVERMANN, B. W. DONAHUE D.J., HERERRAOSTERHELD, S., BURR, G. S. Extremely large variations of atmospheric ${ }^{14} \mathrm{C}$ concentrations during the last glacial period. Science, v. 292, p. 2453-2458, 2001.

BETTI, M.; ALDAVE DE LAS HERAS, L.; JANSSENS, A.; HENRI, E.; HUNTER, G.; GERCHIKOV, M.; DUTTON, M.; VAN WEERS, A. W. Results of the European Commission Marina II Study Part II--effects of discharges of naturally occurring radioactive material. J. Environ. Radioactivity, v. 74, n.1-3, p. 255-277, 2004. 
BOURDON, B.; TURNER, S. P.; HENDERSON, G. M.; LUNDSTROM, C. C. Introduction to U-series geochemistry. In: BOURDON, B.; HENDERSON,G. M.; LUNDSTROM , C.C.; TURNER, S.P. (Ed.). Uranium series geochemistry. Geochemical Society and Mineralogical Society of America, 2003. p. 1-21.

BROECKER, W. S.; SUTHERLAND, S.; SMETHIE, W.; PENG, T.H.; ÖSTLUND, G. Oceanic radiocarbon: Separation of the natural and bomb components. Global Biogeochem. Cycles, v. 9, n. 2, p. 263-288, 1995.

BURNETT, W. C.; DULAIOVA, H. Estimating the dynamics of groundwater input into the coastal zone via continuous radon-222 measurements. J. Environ. Radioactivity, .v. 69, n. 1-2, p. 21-35, 2003.

BURNETT, W. C.; GLENN, C. R.; YEH, C. C.; SHULTZ, M.; CHANTON, J. P.; KASHGARIAN, M. U-series, ${ }^{14} \mathrm{C}$, and stable isotope studies of recent phosphatic "protocrusts" from the Peru margin. In: GLENN,C. R.; LUCAS, L.P.; LUCAS, J. (Ed.). Marine Authigenesis: From Global to Microbial. Tulsa, UK: Society for Sedimentary Geology. p. 163-183, 2000.

BURNETT, W.; BOKUNIEWICZ, H.; HUETTEL, M.; MOORE, W. S.; TANIGUCHI, M. Groundwater and pore water inputs to the coastal zone. Biogeochemistry, v. 66, n. 3, p. 3-33, 2003 .

BURNETT, W. C.; AGGARWAL, P. K.; AURELI, A; BOKUNIEWICZ, H.; CABLE, J. E.; CHARETTE, M. A.; KONTAR, E.; KRUPA, S. et al. Quantifying submarine groundwater discharge in the coastal zone via multiple methods. Sci. Total Environment, v. 367, n. 23, p. 498-543, 2006.

CABLE, J. E.; BURNETT, W. C.; CHANTON, J. P.;WEATHERLY, G. L. Estimating groundwater discharge into the northeastern Gulf of Mexico using radon-222. Earth Planet. Sci. Letts, v. 144, n. 3-4, p. 591-604, 1996.

CARROLL, J.; LERCHE, I.; ABRAHAM, J.D.; CISAR, D.J. Sediment ages and flux variations from depth profiles of ${ }^{210} \mathrm{~Pb}$ : lake and marine examples. Appl. Radiat. Isotopes, v. 50, n. 4, p. 793-804, 1999.

CHARETTE, M.A.; SPLIVALLO, R.; HERBOLD, C; BOLLINGER, M.S. ; MOORE, W.S. Salt marsh submarine groundwater discharge as traced by radium isotopes. Mar. Chem., v. 84, n. 1-2, p. 113-121, 2003.

COCHRAN, J. K.; FENG, H.; AMIEL, D.; BECK, A. Natural radionuclides as tracers of coastal biogeochemical processes. J. Geochem. Explor., v. 88, n. 1-3, p. 376-379, 2006

COCHRAN, J.K. ;MASQUE, P. Natural radionuclides applied to coastal zone processes. In: LIVINGSTON, H. D. (Ed.). Marine Radioactivity. Amsterdam:Elsevier, 2004. p. $1-20$

COHEN, J. E.; SMALL, C.; MELLINGER, A.; GALLUP, J.; SACHS, J. Estimates of coastal populations. Science, $v$. 278, n. 1209-1213, 1997.

CORBETT, D.; BURNETT, W.; CABLE, J.E.; CLARK, S.B. A multiple approach to the determination of Radon fluxes from sediments. J. Radioanalyt. Nucl. Chem., v. 236, p. 247-252, 1998.

CUNHA, I.; FABRA, E.L. 137-Cs radioactivity data in Brazil. Fresenius Environ. Bull. v. 4, p. 19-24, 1995

CUNHA, I. I. L.; MUNITA, C. S.; PAIVA, R. P.; TEIXEIRA, A. Levels of cesium-137 in seawater and fish from the Brazilian coast. Sci. Total Environment, v. 139-140, p. 431-435, 1993.

CUNHA, I.; FIGUEIRA, R.C.L.;SAITO, R.T. Application of radiochemical methods and dispersion model in the study of environmental pollution in Brazil. J. Radioanalyt. nucl. Chem., v. 239, n. 3, p. 477-482, 1999.

DIEGUES, A.C. Human populations and coastal wetlands: Conservation and management in Brazil. Ocean Coast. Mgmt, v. 42, p. 187-210, 1999.

DILLENBURG, S.R.; TOMAZELLI, L.J.; BARBOZA, E.G. Barrier evolution and placer formation at Bujuru southern Brazil. Mar. Geol., v. 203, n. 1-2, p. 43-56, 2004.

DULAIOVA, H.; PETERSON, R.; BURNETT, W.; LANESMITH, D. A multi-detector continuous monitor for assessment of ${ }^{222} \mathrm{Rn}$ in the coastal ocean. J. radioanalyt. nucl. Chem., v. 263, n. 2, p. 361-365, 2005.

DULAIOVA, H.; BURNETT, W. C.; CHANTON, J. P.; MOORE, W. S.; BOKUNIEWICZ, H. J.; CHARETTE, M. A.; SHOLKOVITZ, E. Assessment of groundwater discharges into West Neck Bay, New York, via natural tracers. Continent. Shelf Res., v. 26, n. 16, p. 19711983, 2006.

EKAU, W.; KNOPPERS, B. A review and re-definition of the large marine ecosystems of Brazil. In: Hempel, G.; Sherman, K. (Ed.). Large marine ecosystems of the World. Amsterdam: Elsevier, 2003. p. 355-372.

FERNANDES, H. M.; CARDOSO, K.; GODOY, J. M.; PATCHINEELAM, S.R. Cultural impact on the geochemistry of sediments in Jacarepagua lagoon, Rio de Janeiro, Brazil. Environ. Technol., v. 14, p. 93-100, 1993.

FERNANDES, H. M., ROCHEDO, E. R. R.; AMARAL, E. C. S.; PIRES do Rio, M. A. A code of practice to control TENORM impact of the non-uranium mining industry. Intern.Congress Series, n. 1225, p. 111-119, 2002.

FIGUEIRA, R.C.L.; CUNHA, I. Determination of Strontium90 in fish samples of Brazilian coast. J. Radioanalyt. Nucl. Chem., v. 200, n. 6, p. 497-507, 1995a.

FIGUEIRA, R. C. L.; CUNHA, I. Strontium-90 Levels in seawater samples in Brazil. Fresenius Environ. Bull. v. 4, p. 91-96, 1995b.

FIGUEIRA, R.C.L.; CUNHA, I.I.L. A contaminacao dos oceanos por radionuclideos antropogenicos. Quimica Nova. 21(1): 73-77, 1998.

FIGUEIRA, R. C. L.; SARAIVA, E. S. B. G.; CUNHA, I. I. L. Simultaneous analysis of ${ }^{137} \mathrm{Cs},{ }^{90} \mathrm{Sr},{ }^{238} \mathrm{Pu}$ and ${ }^{239+240} \mathrm{Pu}$ in Brazilian seawater. J. Radioanalyt. Nucl. Chem., v. 248, n. 3, p. 801-804, 2001.

FIGUEIRA, R. C. L.; TESSLER, M. G.; de MAHIQUES, M. M.; CUNHA, I. I. L. Distribution of ${ }^{137} \mathrm{Cs}$, ${ }^{238} \mathrm{Pu}$ and ${ }^{239+}$ ${ }^{240} \mathrm{Pu}$ in sediments of the southeastern Brazilian shelf-SW Atlantic margin. Sci. Total Environment, v. 357, n.1-3, p. $146-159,2006$

FREITAS, A.C. ; ALENCAR, A.S. Gamma dose rates and distribution of natural radionuclides in sand beaches-Ilha Grande, Southeastern Brazil. J. Environ. Radioactivity, v. 75, n. 2, p. 211-223, 2004.

GAZINEU, M. H. P.; ARAUJO, A. A.; BRANDAO, Y. B.; HAZIN, C. A.; GODOY, J. M. Radioactivity concentration in liquid and solid phases of scale and sludge generated in the petroleum industry. J. Environ. Radioactivity, v. 81, n. 1, p. 47-54. 2005. 
GODOY, J. M.; CRUZ, R. P. ${ }^{226} \mathrm{Ra}$ and ${ }^{228} \mathrm{Ra}$ in scale and sludge samples and their correlation with the chemical composition. J. Environ. Radioactivity, v. 70, n. 3, p. 199-206, 2003.

GODOY, J. M.; GODOY, M. L. Natural radioactivity in Brazilian groundwater. J. Environ. Radioactivity, v. 85 n. 1, p. 71-83, 2006.

GODOY, J. M.; MOREIRA, I.; WANDERLEY, C.; MENDES, L. B.; BRAGANCA, M. J. A study of Guanabara Bay sedimentation rates. J. Radioanalyt. Nucl. Chem., v. 227, n. 1-2, p. 157-160, 1998a

GODOY, J. M.; MOREIRA, I.; WANDERLEY, C.; SIMOES FILHO, F. F.; MOZETO, A. A. An alternative method for the determination of excess ${ }^{210} \mathrm{~Pb}$ in sediments. Radiat. Protect. Dosimetry, v. 75, n.1-4, p. 111-115, 1998b.

GODOY, J. M.; CARVALHO, Z. L.; FERNANDES, F. C.; DANELON, O. M.; FERREIRA, A. C. M.; ROLDAO, L. A. ${ }^{137} \mathrm{Cs}$ in marine samples from the Brazilian southeastern coastal region. J. Environ. Radioactivity, v. 70, p. 193-198, 2003.

GODOY, J. M.; CARVALHO, F.; CORDILHA, A.; MATTA, L. E.; GODOY, M. L. ${ }^{210} \mathrm{~Pb}$ content in natural gas pipeline residues ("black-powder") and its correlation with the chemical composition. J. Environ. Radioactivity, v. 83, n. 1,p. 101-111, 2005.

GODOY, J. M.; CARVALHO, Z. L.; FERNANDES, F. C.; DANELON, O. M.; GODOY, M. L.; FERREIRA, A. C.; ROLDÃO, L. A. ${ }^{228} \mathrm{Ra}$ and ${ }^{226} \mathrm{Ra}$ in coastal seawater samples from the Ubatuba region - Brazilian southeastern coastal region. Braz. J. Chem. Soc.,v. 17, n. 4, p. 730-736, 2006.

GOUVEA, R. C.; SANTOS, P. L.; GOUVEA, V. A contribution to the study of radioactivity in marine organisms: Dosage of ${ }^{210} \mathrm{Po}$ in Perna perna, L. Sci. total Environment, v. 61, p. 117-120, 1987.

HUGHEN, K.; LEHMAN, S.; SOUTHON, J.; OVERPECK, J.; MARCHAL, O., HERRING, C.; TURNBULL, J. ${ }^{14} \mathrm{C}$ activity and global carbon cycle changes over the past 50,000 years. Science, v. 303, n. 5655, p. 202-207. DOI: 10.1126/science.1090300. 2004.

IVANOVICH, M.; HARMON, S. Uranium series disequilibrium: Applications to earth, marine and environmental sciences. Oxford: Oxford Science Publication, $1992.910 \mathrm{p}$.

KIM, G.; LEE, K.K.; PARK, K.S.; HWANG, D.W. ;YANG, H.S. Large submarine groundwater discharge (SGD) from a volcanic island. Geophys. Res. Letts., v. 30, n. 21, p. 2098, 2003

KIM, G.; RYU, J. W.; YANG, H. S.; YUN, S. T. Submarine groundwater discharge (SGD) into the Yellow Sea revealed by $\mathrm{Ra}-228$ and Ra-226 isotopes: Implications for global silicate fluxes. Earth Planet. Sci. Letts, v. 237, n. 1-2, p.156-166, 2005.

KNOPPERS, B.; EKAU, W. ; FIGUEIREDO, A.G. The coast and shelf of east and northeast Brazil and material transport. Geo-Marine Letts, v. 19, n. 3, p. 171-178, 1999.

LAURIA, D.C. ; GODOY, J.M. Abnormal high natural radium concentration in surface waters. J. Environ. Radioactivity, v. 61, n.2, p. 159-168, 2002.

LEVIN, I.; HESSHAIMER, V. Radiocarbon - A unique tracer of global carbon cycle dynamics. Radiocarbon, $v$. 42 , n. 1, p. 69-80, 2000.
MACARIO, K. D.; ANJOS, R. M.; GOMES, P.R.S.; FIGUEIREDO, J.; A. G.; LACERDA DE SOUZA, C.; BARBOSA, C.F.; COIMBRA, M.M.; ELMORE, D. AMS radiocarbon dating on Campos Basin, Southeast Brazilian Continental Slope. Nuclear instruments and methods in Physics Research Section B: Beam interactions with materials and atoms. p. 223224; 535-539, 2004.

MAHIQUES, M. M.; SILVEIRA, I. C. A.; SOUSA, S. H. M.; RODRIGUES, M. Post-LGM sedimentation on the outer shelf-upper slope of the northernmost part of the Sao Paulo Bight, southeastern Brazil. Mar. Geol., v. 181, n. 4, p. 387-400, 2002.

MAHIQUES, M. M.; TESSLER, M. G.; MARIA CIOTTI, A.; SILVEIRA, I. C. A.; SOUSA, S. H. D. M.; FIGUEIRA, R. C. L.; TASSINARI, C. C. G.; FURTADO, V. V. Hydrodynamically driven patterns of recent sedimentation in the shelf and upper slope off Southeast Brazil. Continent. Shelf Res., v. 24, n. 15, p. 1685-1697, 2004

MAHIQUES, M. M.; BICEGO, M. C.; SILVEIRA, I. C. A.; SOUSA, S. H. D. M.; LOURENCO, R. A.; FUKUMOTO, M. M. Modern sedimentation in the Cabo Frio upwelling system, Southeastern Brazilian shelf. An. Acad. Bras. Ciênc., v. 77, n. 3, p. 535-548, 2005.

MARQUES JR., A. N.; MONNA, F.; SILVA-FILHO, E. V.; FERNEX, F. E.; SIMOES-FILHO, F. L. Apparent discrepancy in contamination history of a sub-tropical estuary evaluated through ${ }^{210} \mathrm{~Pb}$ profile and chronostratigraphical markers. Mar. Pollut. Bull., v. 52, n. 5 , p. 532-539, 2006.

MATTA, L. E.; GODOY, J. M.; REIS, M. C. ${ }^{226} \mathrm{Ra},{ }^{228} \mathrm{Ra}$ and ${ }^{228} \mathrm{Th}$ in scale and sludge samples from the Campos Basin oilfield E\&P activities. Radiat. Protect. Dosimetry, v. 102, p. 175-178, 2002.

MAZZILLI, B.; PALMIRO, V.; SAUEIA, C.; NISTI, M. B. Radiochemical characterization of Brazilian phosphogypsum. J. environ. Radioactivity, v. 49, n. 1, p. 113-122, 2000

MOLISANI, M. M.; MARINS, R. V.; MACHADO, W.; PARAQUETTI, H. H. M.; BIDONE, E. D.; LACERDA, L. D. Environmental changes in Sepetiba Bay, SE Brazil. Region. Environ. Change, v. 4:, p.17-27, 2004.

MOORE, W. S. Large groundwater inputs to coastal environments revealed by ${ }^{226} \mathrm{Ra}$ enrichments. Nature, v. 380, p. 612-614, 1996.

MOORE, W. S. The role of submarine groundwater discharge in coastal biogeochemistry. J. Geochem. Explor., v. 88, n. 1-3, p. 389-393, 2006.

MOREIRA, I.; SAMPAIO, M. F.; GODOY, J. M. ${ }^{210}$ Po and in fish and shelfish from Guanabara Bay, Brazil. Radioprotection - Colloques, n. 37(C1), p. 101-106, 2002.

NIENCHESKI, F.; BAUMGARTEN, M. G. Z.; ROSO, R. H.; BASTOS, L.A.P.B. Oceanografia Química: Levantamento bibliográfico e identificação do estado atual do conhecimento. Rio de Janeiro: Grafline/Programa REVIZEE, 1999.171 p.

OLIVEIRA, G. H.; PEIXOTO, T. C. S.; PATCHINEELAM, S. M.; PATCHINEELAM, S. R.; BAPTISTA-NETO, J. A. ${ }^{210} \mathrm{~Pb}$ dating of recent sediments on three coastal environments of Rio de Janeiro State, Brazil. In: INTERNATIONAL SYMPOSIUM ENVIRONMENTAL GEOCHEMISTRY IN 
TROPICAL COUNTRIES, 4. Departamento de Geoquimica/UFF, Buzios, Brazil, 2004.

OLIVEIRA, J.; BURNETT, W. C.; MAZZILLI, B. P.; BRAGA, E. S.; FARIAS, L. A.; CHRISTOFF, J.; FURTADO, V. V. Reconnaissance of submarine groundwater discharge at Ubatuba coast, Brazil, using ${ }^{222} \mathrm{Rn}$ as a natural tracer. J. Environ. Radioactivity, v . 69, n.1-2, p. 37-52, 2003.

OLIVEIRA, J.; COSTA, P.; BRAGA, E. S. Seasonal variations of Rn-222 and SGD fluxes to Ubatuba embayments, Sao Paulo. J. Radioanalyt. Nucl. Chem., v. 269 , n. 3, p. $689-695,2006$

PASCHOA, A. S. More than forty years of studies of natural radioactivity in Brazil. Technology, v. 7, p. 193-212, 2000.

PASCHOA, A. S.; GODOY, J. M. The areas of high natural radioactivity and TENORM wastes. Int. Congress Series, n. 1225, p. 3-8, 2002.

PATCHINEELAM, S. R.; SMOAK, J. M. Sediment accumulation rates along the inner eastern Brazilian continental shelf. Geo-Marine Letts., v. 19, n. 3, p. 196-201, 1999.

RAMA MOORE, W. S. Using the radium quartet for evaluating groundwater input and water exchange in salt marshes. Geochim. Cosmochim. Acta, v. 60, n.23, p. 4645-4652, 1996.

SAITO, R. T.; CUNHA, I. ${ }^{210} \mathrm{~Pb}$ and ${ }^{210} \mathrm{Po}$ levels in sediments, water, and bioindicators in the CananeiaIguape estuary - Sao Paulo - Brazil. Czechoslovak J. Phys., v. 53(Suppl. A), p. A75-A81, 2003.

SAITO, R. T.; FIGUEIRA, R. C. L.; TESSIER, M. G.; CUNHA, L. L. L. ${ }^{210} \mathrm{~Pb}$ and ${ }^{137} \mathrm{Cs}$ geochronologies in the Cananeia-Iguape estuary (São Paulo, Brazil). J. Radioanalyt. Nucl. Chem., v. 249, p. 257-261, 2001.

SANDERS, C. J.; SANTOS, I. R.; SILVA-FILHO, E. V.; PATCHINEELAM, S. R. Mercury flux to estuarine sediments, derived from $\mathrm{Pb}-210$ and $\mathrm{Cs}-137$ geochronologies (Guaratuba Bay, Brazil). Mar. Pollut. Bull., v. 52, n. 9, p. 1085-1089, 2006

SANTOS, A. J. G.; MAZZILLI, B. P.; FÁVARO, D. I. T. Characterization of stockpiled phosphogypsum waste in Santos basin, Brazil. Radioprotection - Colloques, 37 . p. 1307-1313, 2002.

SANTOS, A. J. G.; SILVA, P. S. C.; MAZZILLI, B. P.; FAVARO, D. I. T. Radiological characterisation of disposed phosphogypsum in Brazil: Evaluation of the occupational exposure and environmental impact Radiat. Protect. Dosimetry (2006), 1 of 7 doi:10.1093/rpd/ncl011.

SAUEIA, C. H.; MAZZILli, B. P.; FAVARO, D. I. T. Natural radioactivity in phosphate rock, phosphogypsum and phosphate fertilizers in Brazil. J. Radioanalyt. Nucl. Chem., v. 264, n. 2, p. 445-448, 2005.

SAUEIA, C. H. R.; MAZZILLI, B. P. Distribution of natural radionuclides in the production and use of phosphate fertilizers in Brazil. J. Environ. Radioactivity, v.89, n.3, p. 229-239, 2006.

SILVA, M. A. M. Provenance of heavy minerals in beach sands, southeastern Brazil: from Rio Grande to Chui (Rio Grande do Sul State). Sedim. Geol., v. 24, n.1-2, p. 133$148,1979$.

SILVA, P. S. C., MAZZILLI, B. P.; FÁVARO, D. I. T. Distribution of $U$ and $T h$ decay series and rare earth elements in sediments of Santos Basin: Correlation with industrial activities. J. Radioanalyt. Nucl. Chem., v. 264, 2, p. 449-455, 2005.

SILVA, P. S. C.; MAZZILLI, B. P.; FÁVARO, D. I. T. Environmental contamination by technologically enhanced naturally occurring radioactive material TENORM: A case study of phosphogypsum. J. Radioanalyt. Nucl. Chem., v. 269, n. 3, p. 739-745, 2006.

SMITH, J. N. Why should we believe ${ }^{210} \mathrm{~Pb}$ sediment geochronologies? J. Environ. Radioactivity, v. 55, n. 2, p. 121-123, 2001.

SMOAK, J. M.; PATCHINEELAM, S. R. Sediment mixing and accumulation in a mangrove ecosystem: Evidence from, ${ }^{210} \mathrm{~Pb},{ }^{234} \mathrm{Th}$ and ${ }^{7} \mathrm{Be}$. Mangroves Salt Marsh., v. 3, p. 17- 27, 1999.

SMOAK, J. M.; SWARZENSKI, P. W. Recent increases in sediment and nutrient accumulation in Bear Lake, Utah/Idaho, USA. Hydrobiologia, v. 525, p. 175-184, 2004.

SONKE, J. E.; BURNETT, W. C.; HOOGEWERFF, J. A.; VAN DER LAAN, S. R., VANGRONSVELD, J; CORBETT, D. Reconstructing $20^{\text {th }}$ century lead pollution and sediment focusing in a peat land pool (Kempen, Belgium), via ${ }^{210} \mathrm{~Pb}$ dating. J. Paleolimnol., v. 29, p. 95-107, 2003.

SOUZA, M. C.; ANGULO, R. J.; TESSLER, M. G.; FIGUEIRA, R. C. L. Taxas de sedimentação no complexo estuarino da Baía de Paranaguá, Estado do Paraná, estimadas a partir do método de datação por espectrometria gama: resultados preliminares. In: CONGRESSO DA ABEQUA, 7. Imbé, Brazil: ABEQUA, p. 182-183, 2001.

STUIVER, M.; BRAZIUNAS, T. F. Modeling atmospheric ${ }^{14} \mathrm{C}$ influences and ${ }^{14} \mathrm{C}$ ages of marine samples to 10,000 BC. Radiocarbon, v. 35, n. 1, p. 137-189, 1993.

STUIVER, M.; POLACH, H. A. Reporting of ${ }^{14} \mathrm{C}$ data. Radiocarbon, v. 19, n. 3, p. 355-363, 1977.

TOLDO, E. E.; DILLENBURG, S. R.; CORREA, I. C. S.; ALMEIDA, L. E. S. B. Holocene sedimentation in Lagoa dos Patos Lagoon, Rio Grande do Sul, Brazil. J. Coast. Res., v. 16, n. 3, p. 816-822, 2000.

WILKEN, R. D.; MOREIRA, I.; REBELLO, A. ${ }^{210} \mathrm{~Pb}$ and ${ }^{137} \mathrm{Cs}$ fluxes in a sediment core from Guanabara Bay, Brazil. Sci. Total Environ., v. 58, n. 1-2,p. 195-198, 1986.

WINDOM, H.; NIENCHESKI, F. Biogeochemical processes in a freshwater-seawater mixing zone in permeable sediments along the coast of Southern Brazil. Mar. Chem., v. 83, n. 3-4, p. 121-130, 2003.

WINDOM, H. L. Contamination of the marine environment from land-based sources. Mar. Pollut. Bull., v. 25, n. 14, p. 32-36, 1992

WINDOM, H. L.; MOORE, W. S.; NIENCHESKI, F.; JAHNKE, R. A. Submarine groundwater discharge: A large, previously unrecognized source of dissolved iron to the South Atlantic Ocean. Mar. Chem., v. 102, p. 252-266, 2006

(Manuscript received 21 June 2007; revised 13 November 2007; accepted 29 November 2007) 